\title{
Issues of interference and foreign borrowings in the Uzbek language
}

\author{
Isakova Nodira Azzamovna ${ }^{\mathbf{1}}$ \\ ${ }^{1}$ Doctorate student, Samarkand State University, Samarkand, Uzbekistan \\ Email: isakovann@umail.uz
}

\begin{abstract}
The problems of intercultural communication are becoming especially acute, within the framework of which contacts of speakers of different cultures and languages are considered, where language acts as the main attribute of identity.
\end{abstract}

Keywords: foreign, language, integration, global processes.

\section{INTRODUCTION}

Nowadays the integration of Uzbekistan into European and global processes has led to the development of the cultural characteristics of other countries. The main object of study in this article is the new lexical units in the modern Uzbek language, borrowed from foreign languages, their distribution and scope of use. The analyzed group of lexical units is considered in parallel as part of the vocabulary of the modern Uzbek language and in its professionally stylistic versions, as well as at the level of the press language.

The functioning of this rapidly growing lexical group reflects a wide range of social processes taking place in modern Uzbekistan. This borrowed composition of the lexical system of the language testifies to the scientific, technical, political and economic progress that the country is experiencing, involved in the processes of globalization. The relevance of the topic of this article is due to the insufficient study of lexical borrowings from Western European languages in terms of their quantity, composition, degree and characteristics of their adaptation or assimilation in the Uzbek language.

Therefore, the systematization, unification and standardization of borrowed Western European vocabulary is of particular importance for the functioning of the literary norm of the Uzbek language. The purpose of this article is to study borrowed vocabulary from foreign languages in the modern Uzbek language. One of the characteristic features of the development of modern civilization is, on the one hand, the tendency toward rapprochement of societies (economic and social globalization), and on the other, the awareness and cultivation of one's own (national, ethnic, regional) identity, the originality of which is most evident against the background interactions with foreign cultures.

The problems of intercultural communication are becoming especially acute, within the framework of which contacts of speakers of different cultures and languages are considered, where language acts as the main attribute of identity. No matter how original and closed the language is, under the current conditions of globalization, it is subject to constant change, and this primarily concerns the lexical sphere of the language, which is directly related to the representation of the human internal and external world.

The expansion and improvement of various areas of material production, science and technology leads to the appearance of new words-terms or whole terminological layers. When studying the development of the language, one can also see the loss of old words, which eventually fade into the background or even completely disappear. New phenomena at the lexical level, caused by the influence of a foreign culture and another language, are usually denoted by the term 'borrowing '.

Lexical interference is defined as borrowing of lexemes of foreign language in bilinguism which was denoted either in transmission of phoneme consequence from one language into another or in changes in the structure of lexemes of native language, or in calked on the model of foreign languages. 
"All interlinguistic changes in the complex of lexical, and also in the functions and usage of lexical units, in their meaning structures" [1]

When an individual's understanding of one language has an impact on his or her understanding of other language, that individual is experiencing language transfer. There can be negative transfers, otherwise known as interference, when the understanding of one language complicates the understanding of another language. Alternatively, there can be positive transfers such that knowing one language can aid in developing skills for a second language. Language interference is the effect of language learners' first language on their production of the language they are learning. It means that the speaker's first language influences his/her second or foreign language.

The effect can be on any aspect of language: grammar, vocabulary, accent, spelling and so on. Language interference is considered as one of error sources (negative transfer) although where the relevant feature of both languages is the same it results in correct language production (positive transfer). The greater the differences between the two languages, the more negative the effects of interference are likely to be. It will inevitably occur in any situation where someone has not mastered a second language.

\section{MAIN PART}

Borrowing is the process when some foreign elements (word or morpheme) are fixed in the language. Borrowing is the inherent component of functioning process and historical change of the language, one of the main sources of enriching dictionary. Borrowed lexes reflect facts of ethnic links, social, economic and cultural relations among linguistic groups. There is a thick layer of ancient Latin borrowings in German languages related to various spheres, and also ancient borrowings from German and Iranian languages in Slavonian languages. Borrowings can be direct and indirect. Many European words were borrowed into Russian language through Polish as "music" (originally Greek word) or «рынок» ("market" from Polish "rynek" originally from German Ring "кольцо, круг”). Sometimes the meaning of the word is fully changed. The word "сарай” belongs to Persian and means "дворец" (it borrowed through Turkic language).

The words can be borrowed in three cases: 1) the word is borrowed itself: manager -менежер, offshore-офшор, design - дизайн etc. 2) form out a new word from its morphemes, they are wordforming calkings: technology-технология; 3) usage of existing word in explaining the meaning which has the same polysemy (it is called semantic calking): the French words of Chance, Restaurant borrowed into Russian as «шанс, ресторан» and into Uzbek as «ресторан».

When several borrowings based on their general meaning and reiteration of some structural element can be united into definite lexical group, the borrowing or at least usage of new foreign word, twin with the words of this group will be facilitated. There several words in modern Russian language borrowed from English language which has the general meaning of person and general element -мен: gentlemen, sportsmen, policemen, records men, congressmen. In XIX- at the beginning of XX century only first two words «джентльмен, спортсмен» were used, then the number of them had increased: «бизнесмен, конгрессмен, кроссмен, бармен, клубмен, супермен» еtс. [2:25-26].

Nowadays some of these words were borrowed into modern Uzbek language and often used in press and conversational speech every day. For instance, the words as "бизнесмен” or "бармен” are often used almost in all layers of language. In particular, when the newspaper "Khalk suzi" was looked through one can cross out the following borrowings as: модернизация (modernization), электорат (electorate), парламент (parliament), фракция (fraction) etc. Due to the reforms in the economics and industry, these words are often used in the Uzbek language [3].

The borrowed lexis is structurally non-homogeneous. They can be divided into three groups:

1) Words are structurally homogenous with foreign prototypes, i.e. words which had changed graphically and borrowed by the same phoneme devices of loaned language as: комбайн (combine), интернет (internet), менежмент (management), интенсив (intensive), сервис (service), кредит (credit), бренд (brand) etc.

2) Words which are morphologically formed by means of loaned language as: трансмиллий (trans+national), модернизациялаш (modernize), либераллаштириш (liberalize), инфратузилма (infrastructure), номодификациялашган (non-modified), экотизим 
(ecosystem), интерфаол (interactive), экобоғ (ecopark) etc. These words had formed by adding the word-forming, word-changing suffixes of the Uzbek language.

3) Words which are partly morphologically substituted as: конверсия (conversion), инвестиция (investment), логистика (logistics), инновация (innovation), кооперация (cooperation), пластик карточка (plastic card), стратегия (strategy) etc. [5].

The second and the third types of borrowings are close. And also, it's important to differentiate such word-terms which include Greek and Latin elements as telephone, telegraph, stenograph and others, because they have some specific features in comparison with ordinary borrowings.

Forming of scientific and technic terms by using Greek and Latin basis and word-forming elements is the usual case nowadays and they adopted both in many languages and in the world practice. Specifics of that is they haven't native place, living source of borrowing as other foreign borrowings. These terms which are the definite lexical layer of any language prove about internationalization of definite lexis-tendency, which is called as specific feature of all modern relations of languages and nations in linguistic literature [2:44-45].

In present period of industrialization and reforms Uzbek language borrowed many foreign words which denote the specific changes and innovations in all spheres of life. They can be divided into several thematic groups as economics (инвестиция-investment, инвестор- investor, баланс-balance, бизнес-business)

policy (резолюция-resolution, концепция-conception, стратегия- strategy, конвенция-convention, реконструкция-reconstruction, сити-сіty, логистика-logistics, сенатор-senator, парламент-parliament, брифинг-briefing, видеоселектор-video selector),

bank (диверсификация-diversification, субсидия-subsidy, преференция-preferential)

education (лицей-lyceum, коллеж-college, грант-grant, контракт-contract)

geography (миграция-migration, делимитация-delimitation, демаркация-demarcation),

agriculture (агрофирма-agrofirm, фермер-farmer, кластер-claster, дренаж-drainage),

mobile relations (оператор-operator, онлайн-online, офлайн-offline, веб-сайт-web-site, портал-роrtal, смартфон-smartphone, смарт соат-smartwatch, стикер-sticker, дизайн-design, виртуалvirtual,интернет- internet, 3Д графика-3D graphics, ноу-хау--now-how),

medicine (перинатал-perinatal, патронаж-patronage, реабилитация-rehabilitation) and many others [5].

\section{CONCLUSION}

From the above analysis of linguistic material, we can conclude that borrowings from Western European languages are widespread in the modern Uzbek language. Borrowing penetrated almost all of its spheres of functioning: both political, economic, sports, scientific, and everyday. At this stage of the development of the Uzbek language, the active entry and use of foreign words is observed. This contributes to the development of synonymy in the language. It should also be noted that not all newly borrowed words are reflected in dictionaries.

The notable point is that, the words given above are already borrowed and often are used in modern daily and official life in Uzbekistan. In this case, these words are used in the newspaper publications and articles without any changes, and reflect the current reforms and development strategies in our state.

\section{REFERENCES}

1. Blajevich Y.S., Lexical interference in the context of linguistic contact, dissertational abstract. Belgorod, 2011

2. Krisin L.P., Foreign words in modern Russian language, Moscow, 1968, 25-26pp

3. Krysin, L. P. Foreign language in the context of modern public life // Russian language of the late twentieth century (1985-1995). M., 1996. p. 142-161.

4. Linguistic Encyclopedic Dictionary, Moscow, 1967

5. Newspaper "Khalk suzi”, December, 16, 2009, №242 (4905)

6. Newspaper “Khalk suzi”, November-December, 2017, №220-242 (6914-6936) 